\title{
Assessment of the Actual Status of the Cikapundung River Waters in the Densely-Inhabited Slum Area, Bandung City
}

\author{
Edi Rusdiyanto ${ }^{1 *}$, Santun R.P. Sitorus ${ }^{2}$, Bambang Pramudya Noorachmat ${ }^{3}$, \\ Ramalis Sobandi ${ }^{4}$ \\ 1 Indonesia Open University Jl. Cabe Raya, Pondok Cabe, Tangerang Selatan, Banten, Indonesia \\ 2 Department of Soil Science and Land Resource, IPB University, Indonesia \\ 3 Department of Mechanical Engineering, IPB University, Indonesia \\ 4 Urban Expert Researcher, Tunas Nusa Foundation, Bandung, Indonesia \\ * Corresponding author's e-mail: edirus.ut@gmail.com
}

\begin{abstract}
This research was intended to analyze the water quality of the Cikapundung River in Bandung City around the densely-inhabited slums and also to analyze the total number of bacteria coliform and Escherichia coli in the Cikapundung River, Bandung City. The research data was obtained by observing and performing a laboratory analysis through the assessment of environmental quality standard threshold based on the Government Regulation (PP) No. 82 of 2001. The results of laboratory analysis show that the actual condition of water quality of the Cikapundung River is overall classified as polluted, indicating 7 microbiological and physico-chemical parameters which have exceeded the quality standard such as: TSS, DO, BOD, COD, detergent/surfactant, total coliform, and Escherichia coli. In the upper part, there are 6 parameters below the quality standard, consisting of 4 physicochemical parameters and 2 microbiological parameters. In the middle part, there are 8 parameters below the quality standard consisting of 6 physico-chemical parameters and 2 microbiological parameters. In the lower part, there are 6 parameters that exceeded the quality standard consisting of 4 physico-chemical parameters and 2 microbiological parameters. The seasonal difference of parameters averagely has shown that the water quality in the rainy season is better than in the dry season. However, on average, the water sampling taken before flowing to the village has a better quality than past the village.
\end{abstract}

Keywords: densely-inhabited slums, microciological parameters, physico-chemical parameters, water quality

\section{INTRODUCTION}

The increasing number of residents in the City of Bandung has resulted in higher space requirements for residential areas. The area of vegetated land is decreasing due to conversion to built land (Arkham et al., 2013; Rusdiyanto, 2020). If this condition is not taken seriously, it may have the potential to change the pattern of land use for public interest (public goods) such as riverbanks/ borders into land for personal interests (private goods), thus additionally creating the irregularity of urban settlements (Rusdiyanto, 2019). This phenomenon has formed densely-inhabited slum areas, such as those on the outskirts of the Cikapundung River.

On build up land, when it rains, the surface run-off that enters into the river body becomes larger, because the ability of the land to absorb water (infiltration) decreases (Howard and Israfilov, 2002). In addition, the higher the population and the area of built up land is, the more wastewater is produced, especially household waste, which will flow as surface runoff into the Cikapundung River body. It potentially causes flooding and water pollution in the Cikapundung River and has an impact on decreasing the clean water supplies in the dry season. On the basis of this, Brown et al. 
(2009) stated that there are 3 (three) points that must be owned by an ideal city, namely: 1) a city that can function as catchment and water provider (supplier) 2) a city that can provide good ecosystem services 3 ) a city of people and communitiees that care about water. This is the concept of an environmentally-friendly and more productive city with unpolluted river waters.

According to Ferguson et al. (2013) overcoming this problem requires a strategic initiative that focuses on the problems at hand. Therefore, the efforts to minimize water pollution in the Cikapundung River in order to support the realization of an environmentally sound city are very important to implement.

This research/study aimed to analyze the existing conditions: 1) physico-chemical quality of the Cikapundung River water before and after entering the research area (densely-inhabited slums), 2) microbiological quality of the Cikapundung River water which includes the total number of coliform and Esceherichia coli bacteria before and after entering the residential areas in a dense slum area.

\section{MATERIALS AND METHODS}

\section{The location and the time of study}

Sampling of water, as well as collection of data and information was carried out from January to December 2019 in the waters of the Cikapundung River, Bandung City, Indonesia. Water sampling was carried out at 6 location points before and after entering slum densely-inhabited areas, respectively are as follows: The Upper part (Village 200, District Dago), Middle/Central Part (Village Cimaung, District Tamansari), The Lower part (Village Mengger Tengah, District Mengger), as shown in Figure 1. The sampling of river water was carried out in the rainy season (January 2019) and dry season (September 2019).

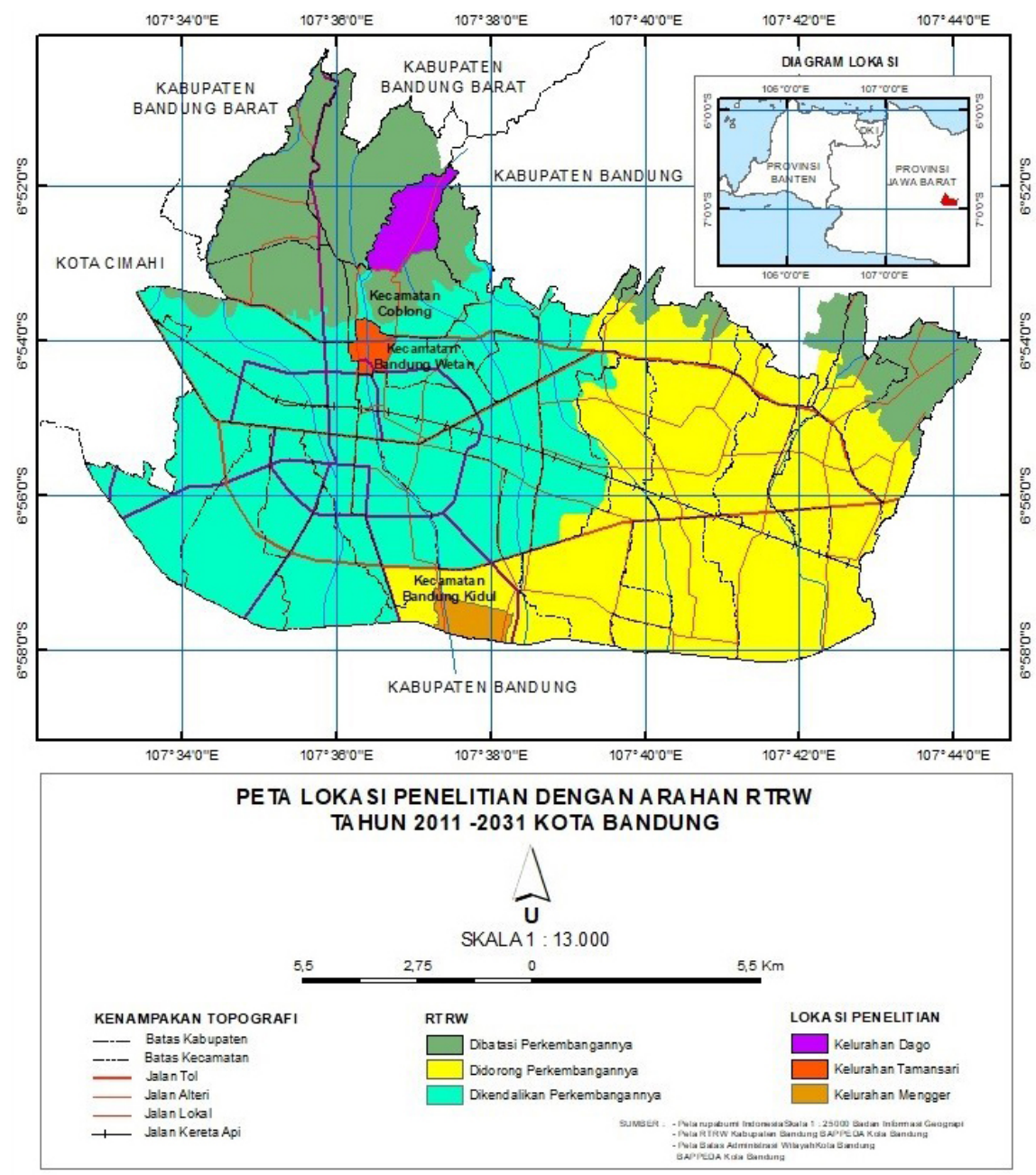

Figure 1. Research location of the Cikapundung River waters 
The primary data was obtained by measuring and calculating the number of samples of water flow from the Cikapundung River. The secondary data was obtained from the literature and related agencies such as Bandung City Environmental Service and Government Regulation (PP) Nomor 82 of 2001. The research data was obtained by observing and taking water samples with the research stages presented in Figure 2. The next stage was taking water samples, temperature readings, testing the level of turbidity, and determining the discharge from each segment and carried out twice at different time. Afterwards, each taken water sample was tested for the levels of Total Suspended Solid (TSS), Total Dissolve Solid (TDS), pH, Dissolved Oxygen (DO), Biochemical Oxygen Demand (BOD), Chemical Oxygen Demand (COD), detergent, total Coliform, and Eschericia coli in the Health Laboratory, Health Office, West Java Province. The data from the laboratory results were then compared with the existing quality standards and are given a category for each location with an environmental quality standard assessment.

The water sampling acitivies were carried out using plastic bottles. For the parameters of total suspended solid and detergents, a 1 liter plastic bottle is used which is then closed tightly and then put into an ice box so that the temperature conditions of the water are maintained and so as not to damage or change the quality of the two parameters. For dissolved oxygen and biochemical oxygen demand levels, a $300 \mathrm{ml}$ winkler was used for water sampling. For DO, after water sampling, $1 \mathrm{ml}$ of $\mathrm{MnSO}_{4}$ and $1 \mathrm{ml}$ of alkali azide were dropped for preservation and stored in the ice box, while for DO after the sample was taken, it was immediately stored in the ice box. A $250 \mathrm{ml}$ pastic bottle was used to take water samples to test the levels of chemical oxygen demand, and after being taken, the sample was preserved by adding $0.5 \mathrm{ml}$ of $\mathrm{H}_{2} \mathrm{SO}_{4}$. The methods and tools for measuring water quality can be seen in Table 1 .

The water sample analysis method was carried out on the analytical procedure of Indonesian National Standard (SNI) on Water and Wastewater which refers to the Standard Methods for the Examination of Water and Wastewater (APHA/ AWWA/WEF 2005). As a reference in analyzing the laboratory results of the Cikapundung River water in this study, class I water quality standards were used. This is because the Cikapundung
River is one of the resources of raw water used in the City of Bandung.

\section{RESULTS AND DISCUSSION}

\section{Actual condition of the cikapundung river water quality}

The river water sampling and laboratory analysis of the water quality of the Cikapundung River were conducted in 2 seasons, namely the rainy season (January 2019) and the dry season (September 2019). The results of the analysis of river water quality are obtained as follows:

\section{Total Suspended Solid}

Total suspended solids or commonly known as TSS are suspended materials (diameter $>1 \mathrm{\pi m}$ ) that are retained on a millipore sieve with a pore diameter of $0.45 \pi m$ (Effendi 2003). TSS consists of mud and fine sand and micro-organisms, which are mainly caused by soil erosion carried into rivers (Billotta and Bazier, 2008). TSS contributes to increasing turbidity in the river and can limit the penetration of light into the river for photosynthesis and its visibility in the river. The results of TTS analysis in the Cikapundung River in 2 seasons are presented in Figure 3.

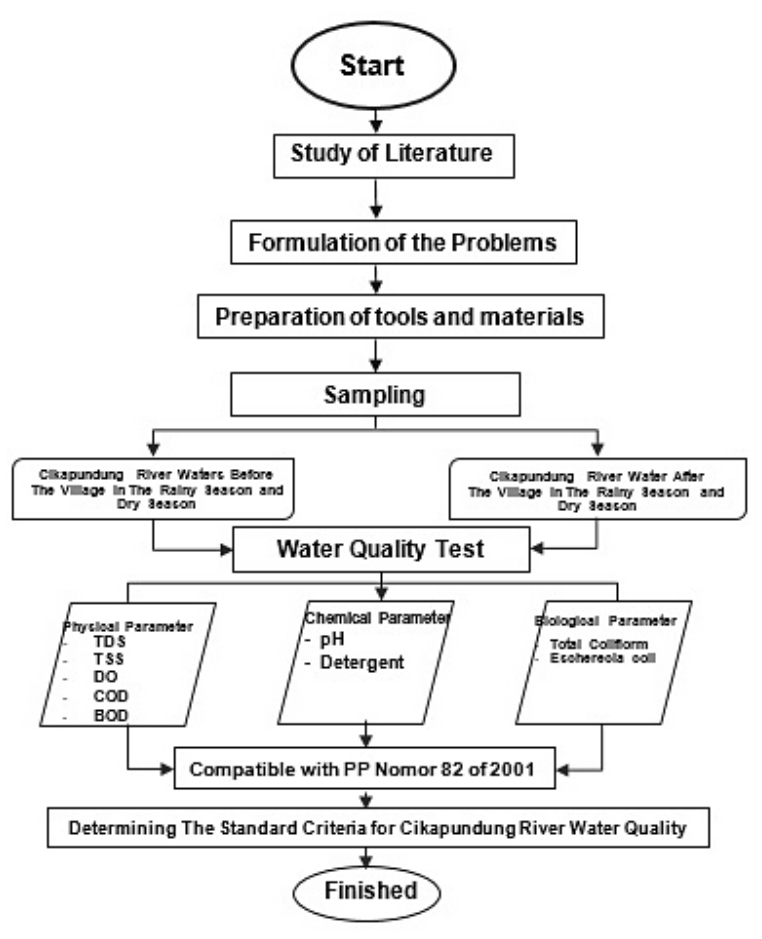

Figure 2. Research flow diagram 
Table 1. Reference for physico-chemical and biological parameter

\begin{tabular}{|c|l|c|l|}
\hline No & Parameter & Units & \multicolumn{1}{|c|}{ Method/Tools used } \\
\hline 1 & TSS & $\mathrm{Mg} / \mathrm{l}$ & SNI 06-6989.3:2004 \\
\hline 2 & TDS & $\mathrm{Mg} / \mathrm{l}$ & SNI 06-6989.27:2005 \\
\hline 3 & $\mathrm{pH}$ & - & SNI 06-6989.11:2004 \\
\hline 4 & $\mathrm{DO}$ & $\mathrm{Mg} / \mathrm{l}$ & SNI 06-6989.14:2004 \\
\hline 5 & $\mathrm{BOD}$ & $\mathrm{Mg} / \mathrm{l}$ & SNI 6989.72:2009 \\
\hline 6 & $\mathrm{COD}$ & $\mathrm{Mg} / \mathrm{l}$ & $\mathrm{SNI} 06-6989.73: 2009$ \\
\hline 7 & Detergent & SNI 06-2476:1991 \\
\hline 8 & Total coliform & total/100 $\mathrm{ml}$ & SNI 01-2897:1992 \\
\hline 9 & Escherecia coli & total/100 $\mathrm{ml}$ & SNI 01-2897:1992 \\
\hline
\end{tabular}

These particles will be suspended in the water and cause turbidity of river water. The high TSS content occurred in the central part sampling location (settlements after entering the village) which was $178 \mathrm{mg} / \mathrm{l}$ and at the central part sampling location (before entering the village) which was $173 \mathrm{mg} / \mathrm{l}$. This condition only occurs in the rainy season, where both TSS contents have exceeded the required environmental quality standard of $50.0 \mathrm{mg} / \mathrm{l}$. The composition and variability of total suspended solids in the Cikapundung River are influenced by the interaction of residential and agricultural wastes (Mucha et al. 2003), sediment-water, changes in salinity and physical processes (river flows) are therefore often difficult to predict (Fardiaz, 1992). This condition can occur because high rainwater runoff will transport soil particles (top soil) as well as organic and inorganic waste into the waters (Rahayu et al. 2018).

\section{Total Dissolve Solid}

TDS is the amount of dissolved solids which is an indicator of the number of the particles in the form of organic and inorganic compounds. The results of the TDS analysis of river water in

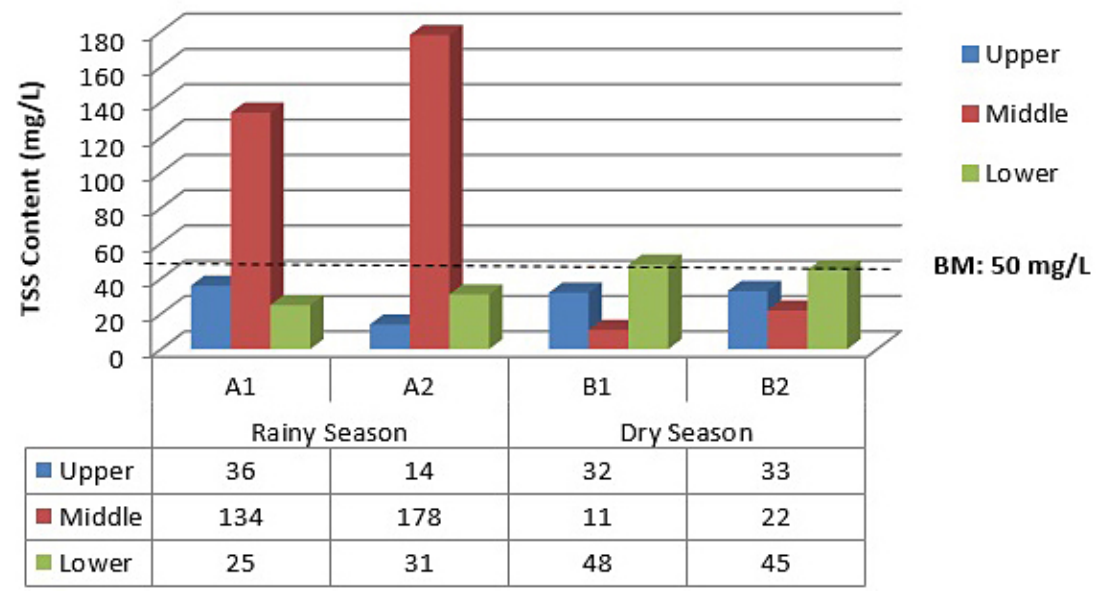

Figure 3. Chart of TSS content in the waters of the Cikapundung River

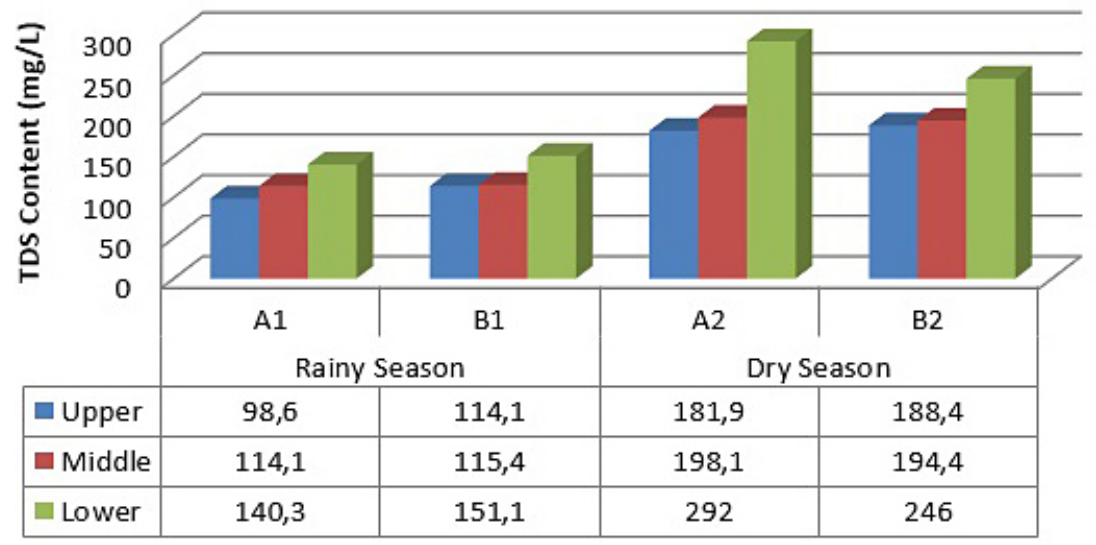

Figure 4. Chart of total dissolve solid in the Cikapundung River 
2 seasons in the Upper, Middle, and Lower parts are shown in Figure 4.

Figure 4 shows the average TDS concentration of the river water samples in the rainy season is lower than in the dry season. In the rainy season, the concentration of TDS before entering the research village (A1) is lower than after entering the research village (B1), while in the dry season the concentration of TDS before entering the research village (A2) in the Upper and Lower Parts is lower than after entering the research village (B2), but in the Middle part it is higher. There is a pattern of the average concentration of TDS in the rainy season and dry season, which always increases downstreams, from the lowest to the highest, respectively, namely Upper, Middle and Lower parts, both in the river water samples before and after entering the research village.

$p H$

The level of acidity/alkaline in the waters is indicated by the $\mathrm{pH}$ value. The $\mathrm{pH}$ ranges from $0-14$, a pH with the number 7 means netral, a $\mathrm{pH}$ less than 7 indicates acidity, while a $\mathrm{pH}$ greater than alkaline. The results of TDS analysis of river water in 2 seasons in the Upper, Middle, and Lower parts are shown in Figure 5.

The measurement results show that the $\mathrm{pH}$ range in the waters of the Cikapundung River in the rainy season and dry season tends to be neutral, which is in the range of $\mathrm{pH} 5.1-8.04$. On the basis of the water quality standards for biota, the $\mathrm{pH}$ value is classified as good for the growth and breeding of river biota. Most aquatic biota are sensitive to changes in $\mathrm{pH}$ and prefer a $\mathrm{pH}$ between 7 - 8,5 (Effendi 2003, Fardiaz 1992). Furthermore, it is mentioned that the $\mathrm{pH}$ value greatly affects the biochemical processes of the waters, such as nitrification process which will cause the $\mathrm{pH}$ of the water to be low. Although there is a $\mathrm{pH}$ concentration that is below the environmental quality standard, this condition is not extreme for the growth of aquatic biota in river waters.

\section{Dissolved Oxygen}

Dissolved oxygen or DO is a relative measure of oxygen dissolved in water that a living thing needs for respirations, growth, and metabolism. The dissolved oxygen levels in rivers vary depending on temperature, salinity, turbulence and atmospheric pressure. The greater the temperature and altitude and the lower the atmospheric pressure, the lower the dissolved oxygen content (Jeffries and Mills 1996). The dissolved oxygen levels also fluctuate daily (diurnal) and seasonally, depending on the mixing and movement (turbulence) of the water mass, photosynthetic activity, respiration and waste (effluent) that enters the river. The results of DO measurements in the Cikapundung River in 2 seasons are presented in Figure 6.

Figure 6 shows the DO concentration along the Cikapundung River is very volatile. This can be influenced by several factors, such as temperature (Tian et al. 2011). These results indicate that the average DO concentration of the river water samples in the rainy season is higher than in the dry season, while the average DO concentration before entering the research village (A1 and A2) is higher than after entering the research village (B1 and B2). The average pattern of DO concentration in the rainy season from the highest to the lowest is the Upper, Lower, and Middle Parts, respectively, in the dry season. There is no regular

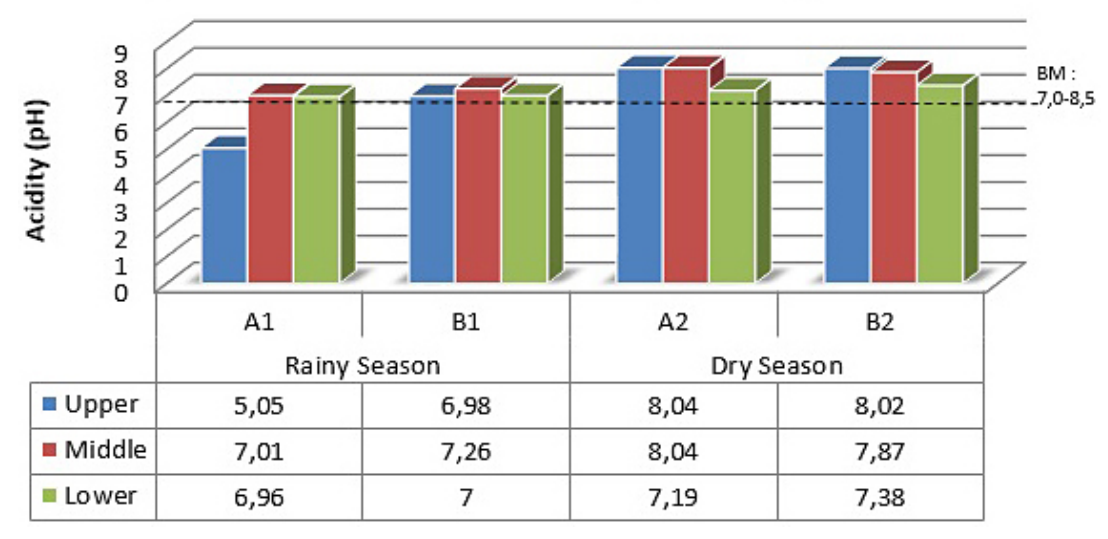

Figure 5. Chart of $\mathrm{pH}$ concentration of the Cikapundung River 


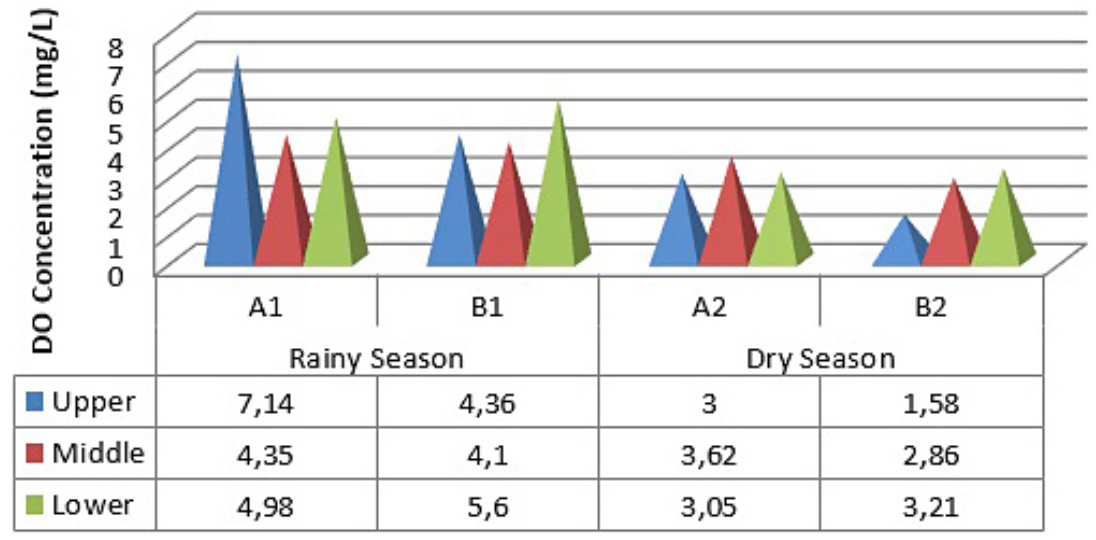

Figure 6. Chart of the DO concentration in the Cikapundung River

pattern where the DO concentration before entering the research village is in the order from the highest, namely the Middle, Lower and Upper Part, while after entering the research village, the DO concentrations are consecutively from the lowest, the Lower, Middle and Upper parts.

For the lowest dissolved oxygen value is in the dry season, the DO value is $1.58 \mathrm{mg} / \mathrm{L}$. This can be influenced by the input of waste from the residential, agricultural, or industrial sectors around the area. In addition, a decrease in the oxygen levels can also occur due to increasing depth, in which the photosynthensis process decreases whereas the available oxygen level is used for respiration and oxidation of organic and inorganic materials.

According to the Government Regulation (PP) No. 82 of 2001, the recommended quality standard is $6 \mathrm{mg} / \mathrm{l}$ for DO value. Furthermore, the chart of dissolved oxygen value in the rainy season shows that in the Upper area the value of $7.14 \mathrm{mg} / \mathrm{L}$ (A1) exceeds the specified quality standard. This condition occurs because of the influence of the overflow of rainwater that enters the river. The oxygen levels in water will increase with lower temperature and decrease with higher salinity. Furthermore, it was stated that oxygen plays an important role as an indicator of water quality, because dissolved oxygen participates in the oxidation and reduction of organic as well as inorganic materials. At a certain pressure, the solubility of oxygen in water is affected by temperature. Other factors that affect the solubility oxygen are turbulence and the surface area of water open to the atmosphere (Mahida 1986).

\section{Biochemical Oxygen Demand}

BOD, commonly known as $\mathrm{BOD}_{5}$, is a description of organic matter levels, namely the amount of oxygen needed by aerobic microbes to oxidize organic matter into carbon dioxide and water (Davis and Cornwell 1991). According to Boyd (1990), BOD indicates the amount of oxygen consumed by the aerobic microbial respiration process contained in a BOD bottle which was incubated at a temperature of about $20^{\circ} \mathrm{C}$ for 5 days in the absence of light. Mays (1996) defines BOD as a measure of the amount of oxygen used by the microbial population contained in the waters in response to the entry of biodegradable organic matter. These organic materials can be in the form of fats, proteins, starch, glucose, aldehydes, and esters. The results of BOD measurements in the waters of the Cikapundung River in 2 seasons are shown in Figure 7.

The results of BOD measurements show that the BOD5 levels in the rainy season are relatively lower than the $\mathrm{BOD}_{5}$ levels in the dry season. This is because the amount of organic matter contained in the waters of the Cikapundung River is relatively small in the rainy season, compared to the content of organic matter in the dry season. Residents' activities, both household waste, agricultural waste and other organic materials, enter the waters of the Cikapundung River. The high content of the existing organic matter causes the high BOD value in the waters of the Cikapundung River. High BOD content can be an indicator of water pollution.

According to Sastrawijaya (1991) the BOD value ranged from 5.1 to $14.9 \mathrm{mg} / \mathrm{L}$, indicating that the waters were classified as moderately polluted and the values $>15.0 \mathrm{mg} / 1$ were 


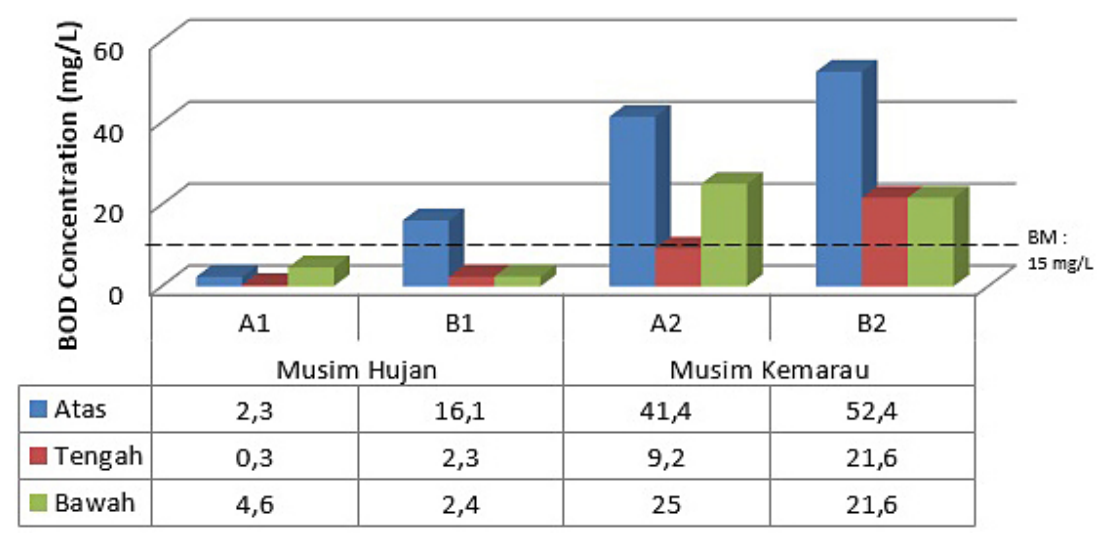

Figure 7. Chart of BOD content in the waters of the Cikapundung River

categorized as heavily polluted. Thus, based on the results of $\mathrm{BOD}_{5}$ measurements, the waters of the Cikapundung River in the rainy season are classified as moderately polluted and in the dry season they are classified as heavily polluted. The high value of $\mathrm{BOD}_{5}$ will cause a decrease in the DO value. This is because the amount of oxygen needed for microbes to break down organic matter will be higher, so that the dissolved oxygen concentration in the waters will decrease. According to Darsono (1995), the free oxygen in water can be reduced if there is degradable organic waste in the water.

\section{Chemical Oxygen Demand}

COD is the total amount of oxygen needed to chemically oxidize organic materials, both those that are easy and those that are difficult to degrade biologically to $\mathrm{CO}_{2}$ and $\mathrm{H}_{2} \mathrm{O}$. In the COD determination procedure, the oxygen consumed is equivalent to the amount of dichromate required to oxidize the sample water (Boyd 1988). A large COD value indicates the amount of oxygen needed for chemical oxidation processes in water. Chemical oxygen demand is also widely used as a measure of the pollution strength of wastewater. The results of COD measurements in the waters of the Cikapundung River in 2 seasons are presented in Figure 8.

The COD measurement results show that the COD levels in the rainy season are relatively lower when compared to the COD levels in the dry season. This is due to the presence of waste that enters the water body. The types of waste that can affect the high value of COD concentration include household waste, agricultural waste, industrial waste, or livestock waste (Lumaela et al. 2013), while the highest waste comes from household waste.

Figure 8 shows the average COD concentration of the river water samples both before and after entering the research village in the rainy season is lower than the dry season. The absence of an average pattern of COD concentrations in the rainy season before entering the research village from the highest to the lowest, respectively,

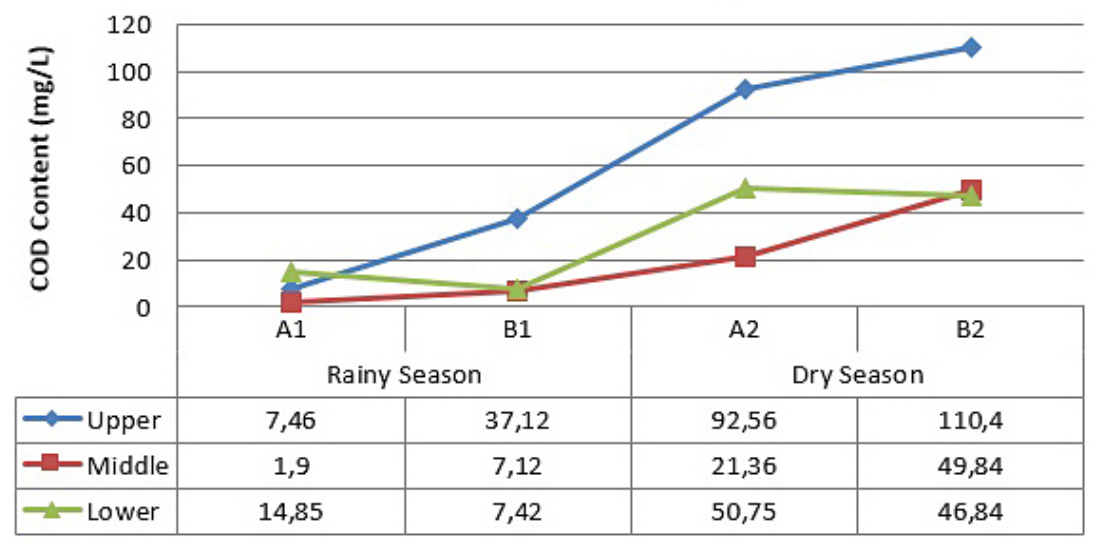

Figure 8. Chart of COD content in the waters of the Cikapundung River 
is the Lower, Upper, and Middle part, while after entering the research village, from the highest to the lowest, the Upper, Lower, and Middle part, respectively. Likewise, in the dry season there is no regular pattern in which the concentration of COD before entering the research village is the order from the highest, namely the Upper, Lower, and Middle parts, while after entering the research village, in succession from the highest, namely the Upper, Middle, and Lower parts.

\section{Detergent (Surfactant)}

Detergent (surfactant) is a chemical compound that can activate the surface of another substance that was not initially able to interact. Surfactant, also known as detergent, is a material in the form of a liquid or powder which is composed of various materials. Detergent is a cleaning agent derived from synthetic chemicals. Surfactant is a material that can cause a decrease in the surface tension of a liquid (Connel and Miller 1995). The main source of surfactant in river waters is domestic waste in the form of detergent (soap). The results of the analysis of detergent measurements in the waters of the Cikapundung River in 2 seasons are presented in Figure 9.

The measurement results show that the detergent concentration in the waters of the Cikapundung River is higher in the rainy season when compared to the concentration of detergent in the dry season. The rainwater runoff that crosses settlements will transport detergent residues into the waters of the Cikapundung River. The condition of settlements that are close to the waters of the Cikapundung River makes it easy for the detergent residues from human activities to enter the river waters. High concentrations of detergents can cause river water pollution.

\section{The total number of bacteria Coliform and Escherichia coli of the Cikapundung River}

\section{Total Coliform}

Coliform bacteria are a class of intestinal bacteria that live in the human digestive tract. The presence of Coliform bacteria in water shows that water is contaminated by pathogenic feces in the intestines, so it is not suitable for consumption (Sopacua et al. 2013). Total Coliform is a description of the total content of coliform bacteria contained in a water. One type of coliform bacteria is Escherichia coli which can be used as a universal bacteriological quality inspection medium on the grounds that Escherichia coli (Ecoli) can normally be found in the human digestive tract as material contaminated with human and animal feces, but is rarely found in water with high quality of hygiene. Another Coliform bacterium which is also often analyzed to determine water quality is Clostridium perfringens, which is a gram-positive, rod-shaped bacterium that forms spores (Fardiaz 1992). These bacteria are usually also found in the feces (stool), although in much less quantity than E. coli. The measurement results of total coliform at the study site are shown in Figure 10.

The measurement results show that the total coliform content in the research location is thought to be influenced by the location of the settlement. The total coliform content after entering the settlement was higher than before entering the village. This is due to the existence

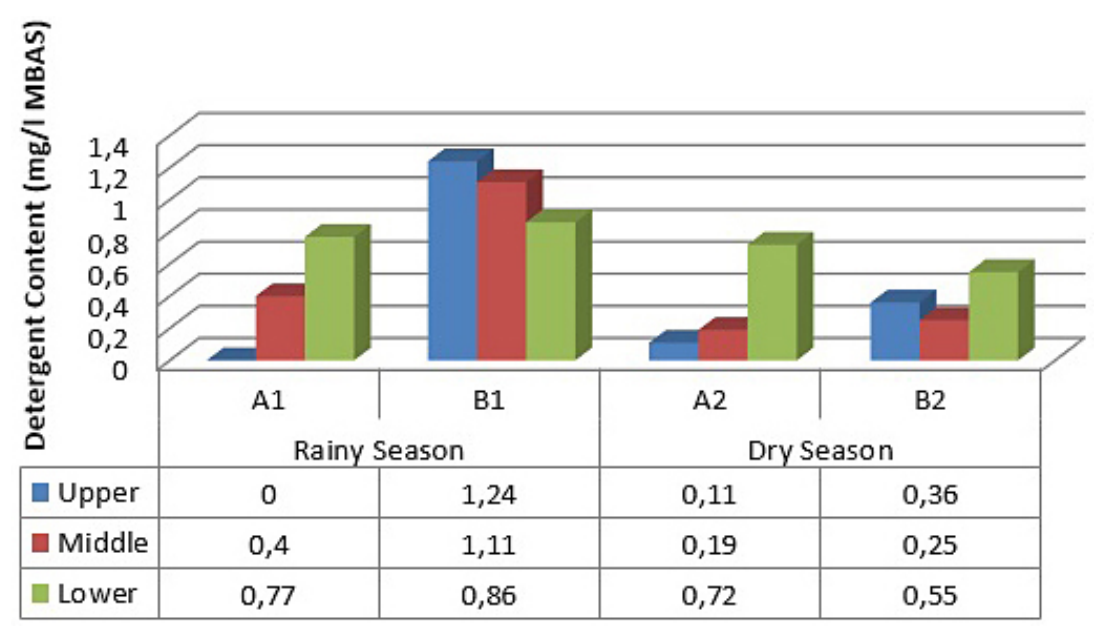

Figure 9. Chart of detergent concentration in the waters of the Cikapundung River 


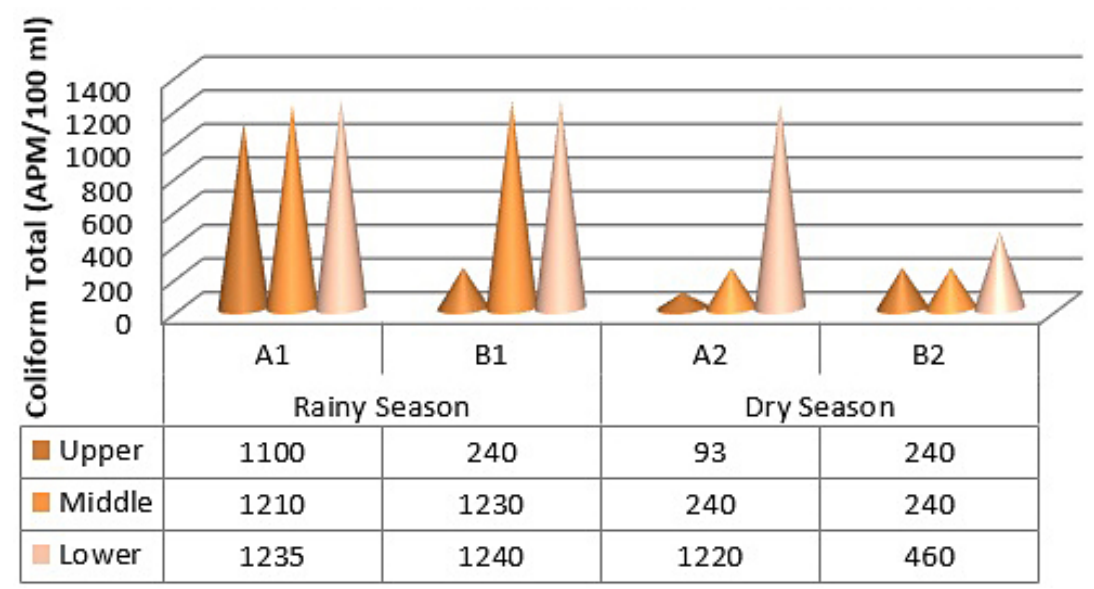

Figure 10. Chart of the total number of Coliform in the waters of the Cikapundung River

of villages around the edge of the Cikapundung River which are not arranged in each residential area in the Upper, Middle, and Lower parts, which are very close to household latrines (septic tanks). On the other hand, the measurement results before entering the village showed that the total coliform content in the waters of the Cikapundung River was low and still below the required environmental quality standard, namely $>1000 \mathrm{MPN} / 100 \mathrm{ml}$ due to the long distance from the residential village. The condition of the village which is very dense and unorganized has resulted in the utilization of river water sources being strongly influenced by the location and distance of the latrines (septic tanks) of high resident waste, indicating that the residents' river water environment contains very high organic matter as a source of microorganism life. According to Sutrisno and Suciastuti (2002) coliform bacteria are the bacteria being an indicator of water pollution by pathogenic bacteria. The water containing coliforms is considered to have been contaminated with human waste (feces).

\section{Total Eschericia coli}

Escherichia coli (E. coli) is an indicator of bacteria for the presence of pathogenic bacteria in water. The source of pollution is from human feces, so if these bacteria are found in water samples, it is an indication that the water contains pathogenic bacteria. The category of sample river distance with septic tank is more than $10 \mathrm{~m}$. This distance was chosen as the starting point, taking into account that the spread of micro-organisms in the soil is only $11 \mathrm{~m}$, so that the ideal distance between the water source (river) and the latrine (septic tank) is at least $10 \mathrm{~m}$ (Ryadi, 1984). In slum settlements, due to limited land, the distance is estimated to be more than $10 \mathrm{~m}$. The results of total Escherichia coli measurements in various parts of the waters of the Cikapundung River in 2 seasons are shown in Figure 11.

The measurement results show that the E. coli content in some river water samples is influenced by the location of the narrow, unorganized settlements as well as the distance of the latrine (septic

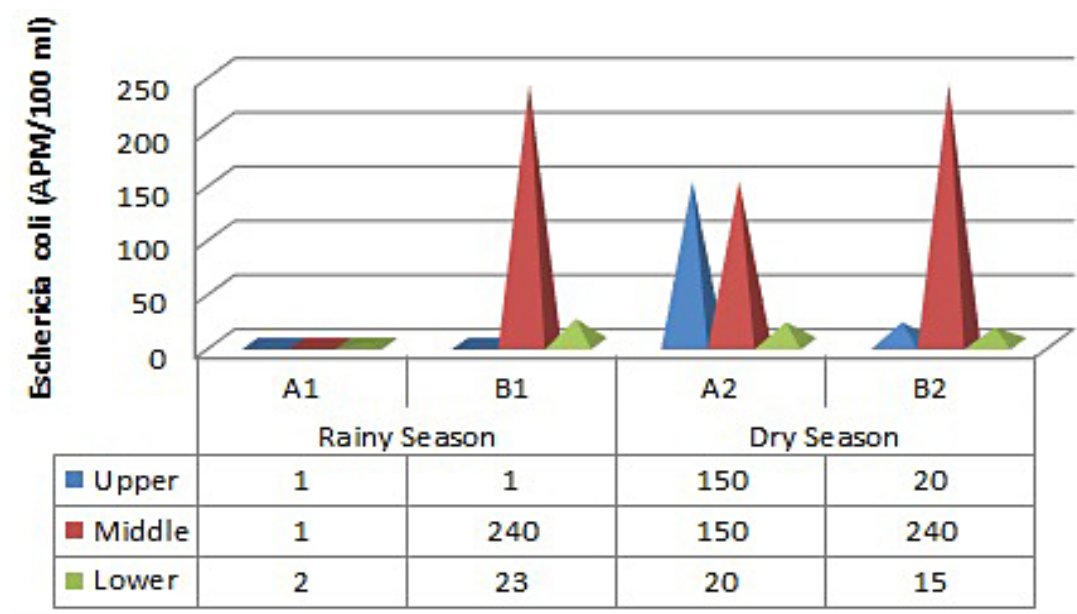

Figure 11. Chart of Escherichia coli contained in the waters of the Cikapundung River 
tank) and water sources. This condition resulted in higher E. coli content after entering the village settlement when compared to the total E. coli content before entering the village at each Upper, Middle and Lower water crossing. The range of the number of E. coli in each section before and after entering the village both around the Upper, Middle and Lower riverwaters shows that in the dry season the average results of the analysis of E. coli content are $>10,000 / 100 \mathrm{ml}$ (Regulation of the Environment Ministry Nomor KEP-58/ MENLH /12/1995). This shows that the river water contains very high organic matter, as a source of microorganism life. This is in accordance with the opinion of Suriawiria (2003), which states that the presence of pathogenic microbes in the water will increase if the organic matter content in the water is high enough, as a place and source of microorganism life. In this case, the residential areas of the Upper, Middle and Lower villages with high population density have the potential to pollute the water sources of the Cikapundung River.

\section{CONCLUSIONS}

Overall, the actual condition of the water quality of the Cikapundung River is classified as polluted, as shown from 7 physico-chemical and microbiological parameters that have exceeded the quality standards, namely TSS, DO, BOD, COD, detergent/surfactant, total coliform, and Escherichia coli. In the Upper Part, the average values of the 7 physico-chemical parameters that exceed the quality standard threshold (BM) are DO, BOD, COD, and detergent, respectively, while the parameters below the BM are TDS, TSS, and $\mathrm{pH}$. Furthermore, the average value of 2 microbiological parameters, namely total coliform and Escherichia coli were also above the BM threshold. In the Middle Part, the average values of the physico-chemical parameters that are above the BM threshold are TDS, TSS, DO, $\mathrm{BOD}, \mathrm{COD}$, and detergent, while the parameters below the $\mathrm{BM}$ are $\mathrm{pH}$. Furthermore, the average value of 2 microbiological parameters, namely total coliform and Escherichia coli were also above the BM threshold. In the Lower Part, the average physico-chemical parameter values that are above the BM threshold include DO, BOD, COD, and detergent, while the parameters below the BM are TDS, TSS, and pH. Furthermore, the average value of 2 microbiological parameters, namely total coliform and Escherichia coli, were above the BM threshold. The average condition of river water quality parameters in the rainy season is better than the dry season, while the average sample of river water before entering a densely-inhabited slum settlement is of better quality than after passing through a densely-inhabited slum village.

\section{Acknowledgments}

We express our gratitude to the Bandung City Public Works Office, the Bandung City Spatial Planning Office, the Bandung City Housing and Settlement Area - Land and Park Office, the West Java Province Housing and Settlement Area Office, and all parties who have helped in this research.

\section{REFERENCES}

1. Arkham, Arifin H.S., Kaswanto R.L., Arifin N.H.S. 2013. Blue Open Space Landscape Management in the Ciliwung Watershed. Proceedings of the National Workshop and Seminar on the Communication Forum of Indonesian Agricultural Universities. Bogor (ID): Bogor Agricultural Institute. (in Indonesian)

2. APHA-AWWA-WEF. 2005. Standard Methods for Examination of Water and Wastewater. American Public Health Association (APHA)-American Water Works Association (AWWA)-Water Environment Federation (WEF).

3. Brown R., Keath N., Wong T. 2009. Urban Water Management in Cities: Historical, Current and $\mathrm{Fu}-$ ture Regimes. Water Science \& Technology, 59(5). Melbourne: IWA Publishing.

4. Bilotta G.S., dan Brazier R.E. 2008. Understanding the Influence of Suspended Solids on Water Quality and Aquatic Biota. Water Research, 42, 2849-2861.

5. Boyd C.E. 1988. Water Quality in Warmwater Fish Ponds. Fourth Printing. Auburn University Agricultural Experiment Station. Alabana, USA.

6. Connell D.W., dan Miller G.J. 1995. Pollution Chemistry and Ecotoxicology. Jakarta (ID): Indonesia University Press. (in Indonesian)

7. Darsono V. 1995. Introduction to Environmental Science. Yogyakarta (ID): Atma Jaya University. (in Indonesian)

8. Davis M.L., dan Cornwell D.A. 1991. Introduction To Enviromental Engineering. 2nd Edition. New York (US): McGraw-Hill Internastional. 
9. Effendi H. 2003. Study of Water Quality for Management of Aquatic Resources and Environment. Yogyakarta (ID): Kanisius Publishers. (in Indonesian)

10. Fardiaz S. 1992. Water and Air Pollution. Yogyakarta (ID): Kanisius Publishers. (in Indonesian)

11. Ferguson B.C., Frantzaskaki N., Brown R.R. 2013. A Strategic Program for Transitioning to a Water Sensitive City. Landscape and Urban Planning, 117, 32-45.

12. Howard K.W.F., Israfilov R.G. 2002. Current Problems of Hydrogeology in Urban Areas, Urban Agglomerates and Industrial Centres. Canada (CA): Kluwer Academic Publishers. Springer-Science Business Media.

13. Jeffries M., dan Mills D. 1996. Freshwater Ecology. Principles, and Aplications. Chichester (UK). John Wiley and Sons.

14. Lumaela A.K., Otok B.W., Sutikno. 2013. Modeling Chemical Oxygen Demand (COD) River in Surabaya with Mixed Geographically Wighted Regression Method. Jurnal Sains dan Seni Pomits ITS, 2(1), 100-105. (in Indonesian)

15. Mahida U.N. 1986. Water Pollution and Utilization of Industrial Waste. Jakarta (ID): Rajawali Publishers. (in Indonesian)

16. Mays L.W. 1996. Water Resources Handbook. New York (US): McGraw-Hill.

17. Mucha A.P., Vasconcelos M.T.S.D., Bordalo A.A. 2003. Macrobentic Community in the Douro Estuary Relation with Trace Metals and Natural Sediment Characteristic. Environment Pollution, 121, 160-180.
18. Rahayu Y., Juwana I., Marganingrum D. 2018. Study on Calculation of River Water Pollution Loads in the Cikapundung Watershed (DAS) from the Domestic Sector. Jurnal Rekayasa Hijau, 2(1), 61-71. (in Indonesian)

19. Ryadi S. 1984. Water Pollution, Environmental Series Basics and Principles of Management. Surabaya (ID): Karya Anda Publishers. (in Indonesian)

20. Rusdiyanto E., Sitorus S.R.P., Pramudya B., Sobandi R. 2020. The Dynamic of Built Land Development in the Cikapundung Riverside Area, Bandung City, Indonesia. Journal of AES Bioflux, 12(2), 146-159.

21. Rusdiyanto E., Sitorus S.R.P., Pramudya B., Sobandi R. 2019. Institutional Analysis In The Area Of Sustainable Settlement In Cikapundung River, Bandung City. Journal of Socio-Economic Public Works, 7(1), 53-63. (in Indonesian)

22. Sastrawijaya A.T. 1991. Environmental Pollution. Jakarta (ID). Rineka Cipta Publisher.

23. Sopacua F.C., Purwijatiningsih L.M.E., Pranata S. 2013. Coliform and Chlorine Content of Ice Cubes in Yogyakarta. Yogyakarta (ID). Atma Jaya University. (in Indonesian)

24. Suriawiria U. 2003. Water in Healthy Living and Environment. Bandung (ID). Alumni Publisher. (in Indonesian)

25. Sutrisno C.T., Suciastuti E. 2002. Clean Water Supply Technology. Jakarta (ID). Rineka Cipta Publisher. (in Indonesian)

26. Tian S., Wang Z., Shang H. 2011. Study on the Selfpurification of Juma River. Procedia Environmental Sciences V. 